\title{
Experimental studies and Development of Modelling equation of Quercetin from Pine apple peel using Soxhlet Extractor
}

\author{
Meena Vangalapati ${ }^{1}$, Srijana $\mathrm{V}^{2}$, Venkata Siva $\mathrm{A}^{3}$, Hima Bindu V N V ${ }^{4}$ and Nareesh V U B ${ }^{5}$ \\ Associate Professor, Dept of Chemical Engineering, AUCE (A), Andhra University, A.P, India ${ }^{1}$ \\ B.Tech. Student, Dept of Chemical Engineering, AUCE (A), Andhra University, A.P, India ${ }^{2}$ \\ B.Tech. Student, Dept of Chemical Engineering, AUCE (A), Andhra University, A.P, India ${ }^{3}$ \\ B.Tech. Student, Dept of Chemical Engineering, AUCE (A), Andhra University, A.P, India ${ }^{4}$ \\ B.Tech. Student, Dept of Chemical Engineering, AUCE (A), Andhra University, A.P, India ${ }^{5}$
}

\begin{abstract}
Quercetin is a flavonoid widely distributed in nature. It is rich in foods including fruits, vegetables, leaves and grains. It has been used in medicine to control the capillary fragility and blood breeding. It shows pharmacological activities like anti-oxidant, anti-cancer, anti-viral and anti- inflammatory activities etc. The present study was intended for the optimization of extraction of Quercetin from pine apple peel and its various physicochemical parameters have been studied. For the extraction of Quercetin the optimum results were observed for the effect of different solvents, soaking time, different solvent percentages, effect of $\mathrm{pH}$, different volumes of hexane with methanol as solvent, extraction time with hexane were methanol, 1day, 80\% (v/v), 7.0, 1:1 ratio and $1 \mathrm{hr}$ respectively. The highest Quercetin concentration for optimized condition was $37 \mu \mathrm{g} / \mathrm{ml}$. Methanol was found to be the best solvent for the extraction of Quercetin from pineapple peel by soxhlet extractor. It was carried out for 90 min and an optimum concentration obtained at $50 \mathrm{~min}$ with a concentration of $50 \mu \mathrm{g} / \mathrm{ml}$. This Solvent extraction using soxhlet extractor was conduct to verify the mathematical model proposed in this work. The final form of proposed models were $\mathrm{E}(\mathrm{t})=$ $\mathrm{At}^{2}+\mathrm{Bt}+\mathrm{C}$ Where $\mathrm{A}, \mathrm{B} \& \mathrm{C}$ are constants, $\mathrm{E}_{\mathrm{s}}=$ yield extract $(\mu \mathrm{g} / \mathrm{ml}$ of quercetin) and $\mathrm{t}=$ extraction time(min). The final form of proposed equation is $\mathrm{E}(\mathrm{t})=-0.018 \mathrm{t}^{2}+1.591 \mathrm{t}$ with $\mathrm{R}^{2}=0.894$.
\end{abstract}

KEY WORDS: Pineapple Peel, Quercetin, Soxhlet extractor, modelling equation, methanol.

\section{INTRODUCTION}

Quercetin is a plant pigment that is soluble in water and belongs to the genre known as bioflavonoids[1]. It is greatly accountable for most of the colors of the fruits, vegetable and flowers. flavonoids like quercetin[2] are useful to the humans as they supply several health[3] enhancement advantages. These flavonoids function as antihistamines and help in lessening allergies and at the same time alleviate inflammation or swelling and pains linked to arthritis. In addition, quercetin also functions as antioxidants and cleans up the damaged particles or free radicals in the body. These free radicals crop up biologically in the body[4] and have the ability to destroy cell membranes, aggravate the aging process, interrelate with inherent substances and also lead to a number of ailments such as heart disease[5] and cancer[6]. Hence, antioxidants [7] like quercetin are able to counteract the free radicals [8] and help in lessening and also preventing the damages caused by them. It has been found that quercetin has the potential to become an effective remedy for prevention and treatment of several disorders [9]. Moreover, it has been observed that quercetin is most effective to treat allergies and inflammations [10] when it is used with a digestive enzyme found in pineapplesbromelain. Pineapples peal contains small amount Vitamin A, vitamin P (rutin), quercetin flavonoid and beta-carotene levels. These compounds are known to have antioxidant properties. 


\title{
International Journal of Innovative Research in Science, Engineering and Technology
}

\author{
(An ISO 3297: 2007 Certified Organization)
}

\section{Vol. 4, Issue 5, May 2015}

\section{MATERIALS AND METHODS}

\section{Chemicals and reagents:}

\section{Equipment:}

Methanol, distilled water, hexane, aluminium chloride, sodium nitrite, sodium hydroxide.

Collection of the plant material:

The pineapple peels are collected from local market at Visakhapatnam, Andhra Pradesh, India.

\section{Processing of the plant material:}

The peels are cleaned, dried under shade and powdered. The powder is then screened using 100 mesh size and the fraction obtained are stored in an air-tight container.

\section{Extract preparation:}

$1 \mathrm{gm}$ of powder is added to $50 \mathrm{ml}$ methanol $(80 \%)$ in a conical flask. The solution is soaked for 1 day. After the soaking time, the solution is filtered using Whatman filter paper no: 1 and the filtrate is heated at $65^{\circ} \mathrm{C}$. so that the solvent which is taken in glassware is evaporated. The resultant solution is cooled and make up to $25 \mathrm{ml}$ with distilled water. This solution is added to $25 \mathrm{ml}$ of hexane taken in a separating funnel. Incubate the solution of methanolic extract for $1 \mathrm{hr}$.

\section{Determination of Quercetin:}

$1 \mathrm{ml}$ of methanolic extract is taken in a test-tube from the extract phase of the separating funnel. To this $0.3 \mathrm{ml}$ of $5 \%$ sodium nitrite was added. After 5 minutes $0.3 \mathrm{ml}$ of $10 \% \mathrm{AlCl}_{3}$ [11] was added. After 6 minutes $2 \mathrm{ml}$ of $1 \mathrm{M}$ sodium hydroxide was added and the mixture was made upto $10 \mathrm{ml}$ by adding distilled water. The absorbance of the reaction mixture was measured at $510 \mathrm{~nm}$ using colorimeter. The concentration of quercetin was determined by using calibration curve.

\section{Solvent extraction using Soxhlet extractor:}

Prior to the solvent extraction study, $200 \mathrm{ml}$ of $80 \%$ methanol is taken in the extractor. $4 \mathrm{gm}$ of dried pineapple peel powder is placed in thimble and it is fixed to the condenser. Now the total apparatus is placed in the heater. Using the soxhlet apparatus [12] continuous extraction is done for $90 \mathrm{~min}$. The entire system was shown in figure 1. Solvent - Solvent extraction was done by hexane as solvent along with distillate of 1:1 ratio in separating funnel. After few minutes of solvent extraction with hexane, two phases like extract and raffinate phases were separated. Now collect $1 \mathrm{ml}$ of extract phase for the determination of quercetin.

\section{RESULTS AND DISCUSSION}

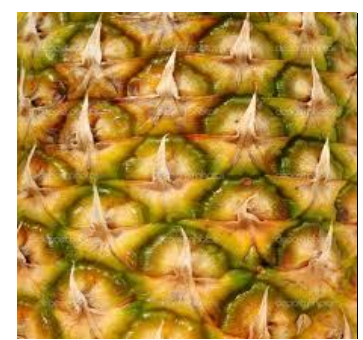

(a)

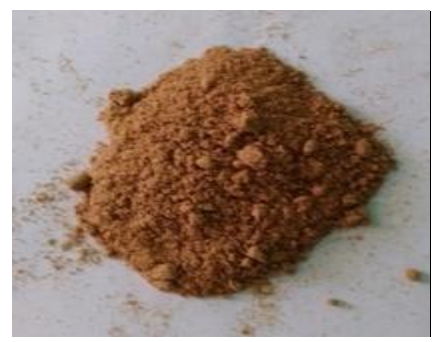

(b)

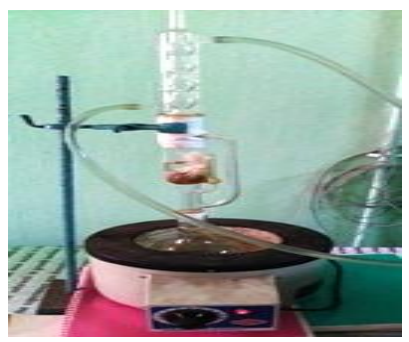

(c)

Fig.1: (a) Pineapple peel

(b) Dried peel powder

(c) Soxhlet extractor 


\section{International Journal of Innovative Research in Science, Engineering and Technology}

(An ISO 3297: 2007 Certified Organization)

Vol. 4, Issue 5, May 2015

A. EFFECT OF PROCESS PARAMETERS:

\section{EFFECT OF DIFFERENT SOLVENTS ON EXTRACTION OF QUERCETIN:}

For the extraction of Quercetin from pineapple peel powder, different organic solvents such as methanol, ethanol, water and ethyl acetate are used. Among these, methanol showed the best results and the concentration of Quercetin and obtained was $9 \mu \mathrm{g} / \mathrm{ml}$.(Fig. 2).

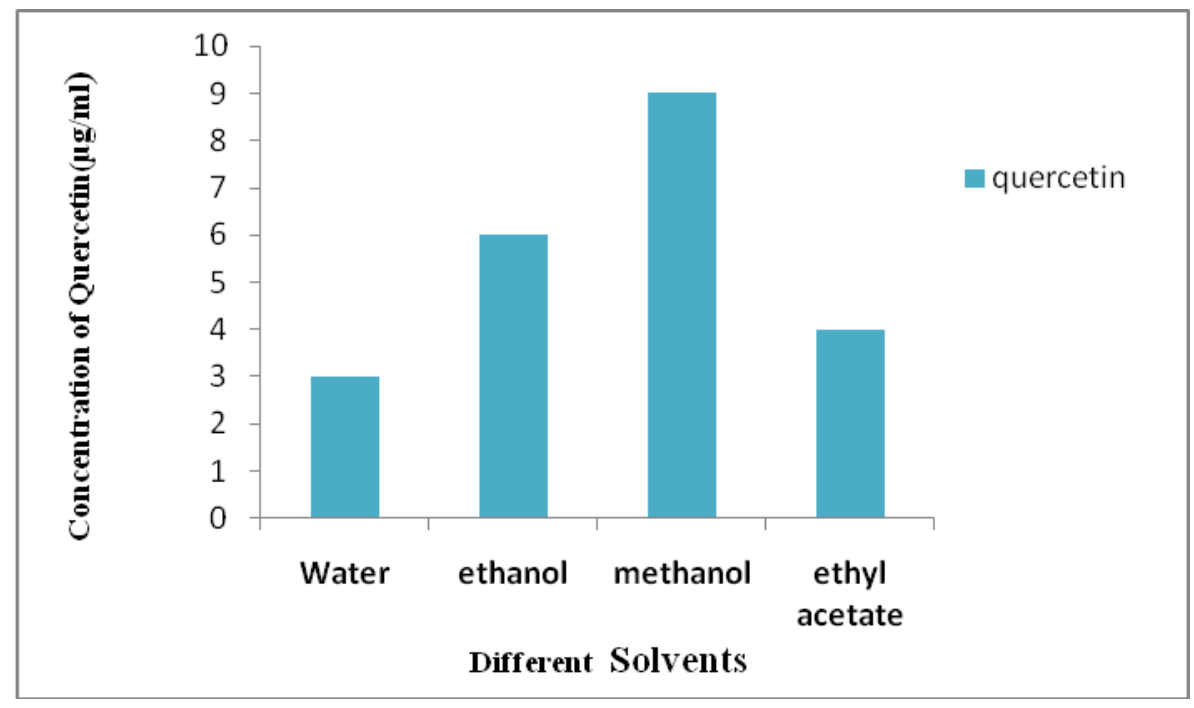

Fig.2. Effect of different solvents on extraction of Quercetin

\section{EFFECT OF SOAKING TIME ON EXTRACTION OF QUERCETIN:}

For the extraction of Quercetin from pineapple peel powder, the samples were incubated for different time periods viz., 1, 2, 3 and 4 days. It was observed that, soaking for 1 day gave the best result and the concentration of Quercetin obtained was $23 \mu \mathrm{g} / \mathrm{ml}$. (Fig. 3)

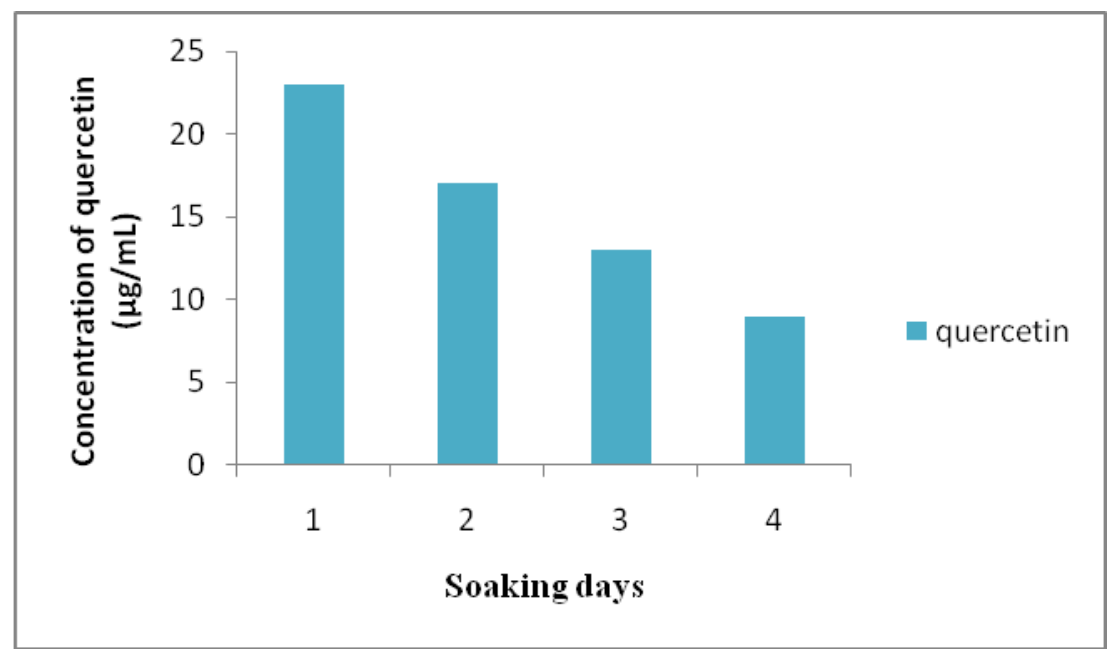

Fig.3. Effect of soaking time on extraction of quercetin 


\section{International Journal of Innovative Research in Science, Engineering and Technology}

(An ISO 3297: 2007 Certified Organization)

Vol. 4, Issue 5, May 2015

\section{EFFECT OF DIFFERENT SOLVENT COMPOSTION ON THE EXTRACTION OF QUERCETIN:}

Different solvent percentages like $0 \%, 20 \%, 40 \%, 60 \%, 80 \%, 100 \%$ of methanol solvent are used for extraction of Quercetin. The optimum solvent percentage was found to be $80 \%$ and its concentration is found to be 23 $\mu \mathrm{g} / \mathrm{ml}$. (Fig. 4)

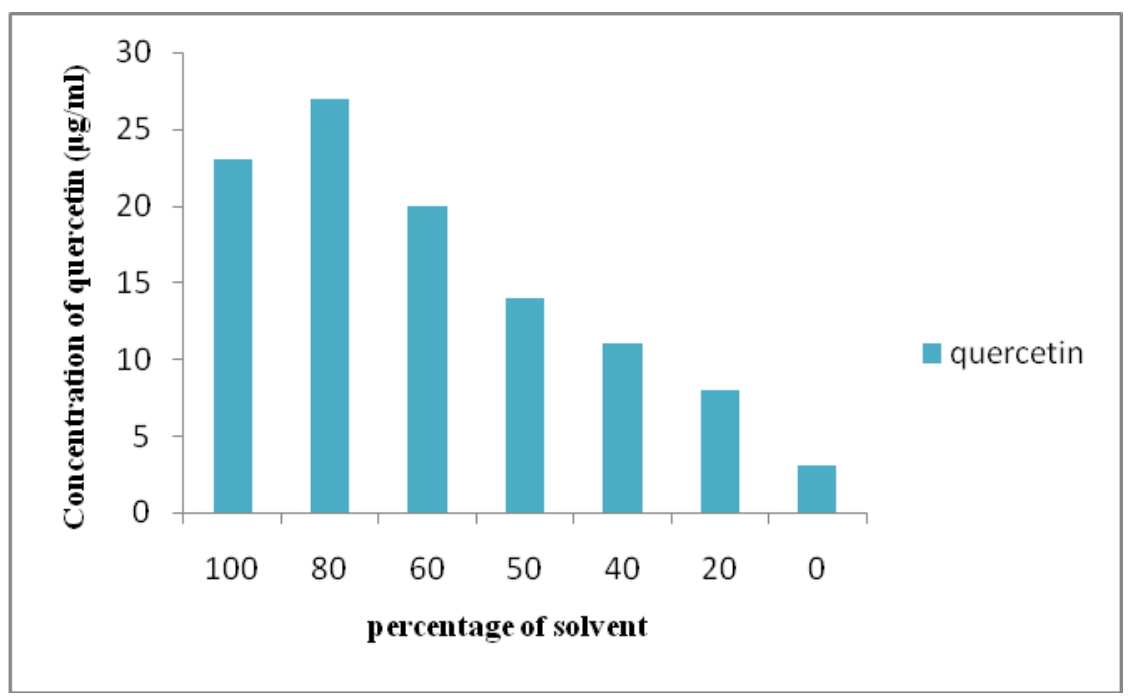

Fig.4. Effect of different solvent compostion on the extraction of quercetin

\section{EFFECT OF $\mathrm{pH}$ ON EXTRACTION OF QUERCETIN:}

To determine the effect of $\mathrm{pH}$ on extraction process different $\mathrm{pH}$ values namely 5, 6, 7, 8 and 9 were used. The optimum concentration of quercetin was $30 \mu \mathrm{g} / \mathrm{ml}$ observed at $\mathrm{pH}$ 7. (Fig. 5)

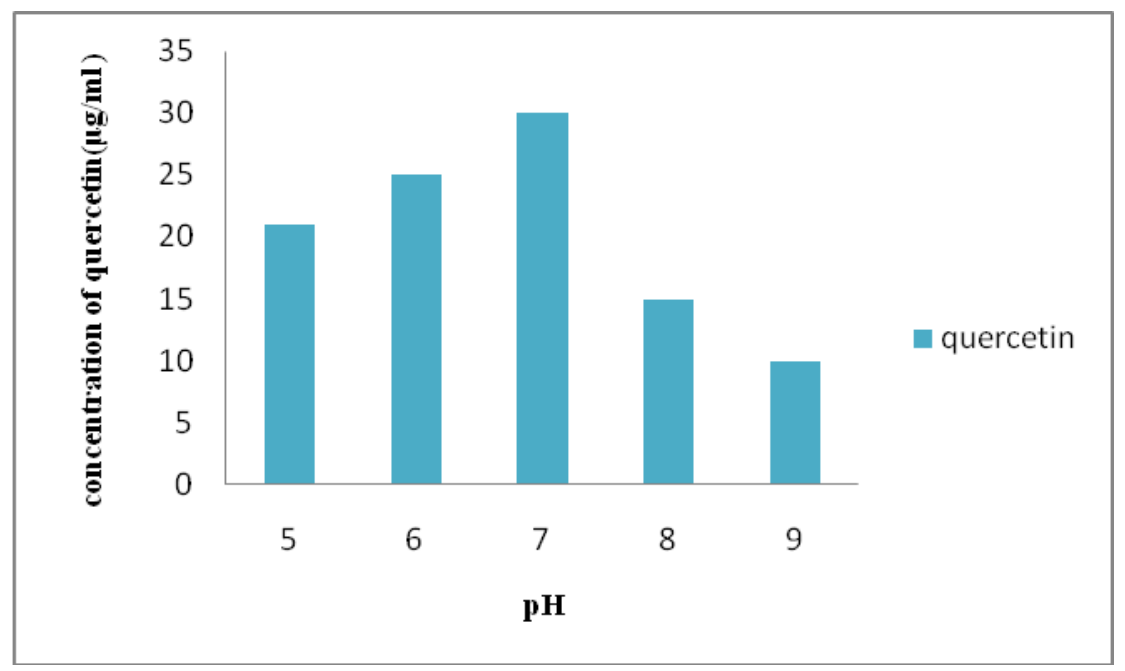

Fig.5. Effect of pH on extraction of quercetin 


\section{International Journal of Innovative Research in Science, Engineering and Technology}

(An ISO 3297: 2007 Certified Organization)

Vol. 4, Issue 5, May 2015

\section{EFFECT OF DIFFERENT VOLUMES OF HEXANE ON THE EXTRACTION OF QUERCETIN:}

Different volumes of hexane with solvent in different ratios such as 1:1, 1:2, and 2:1 are used for the extraction of quercetin. The optimum value is observed with the ratio $1: 1$ and the concentration of quercetin is found to be $25 \mu \mathrm{g} / \mathrm{ml}$. (Fig.6)

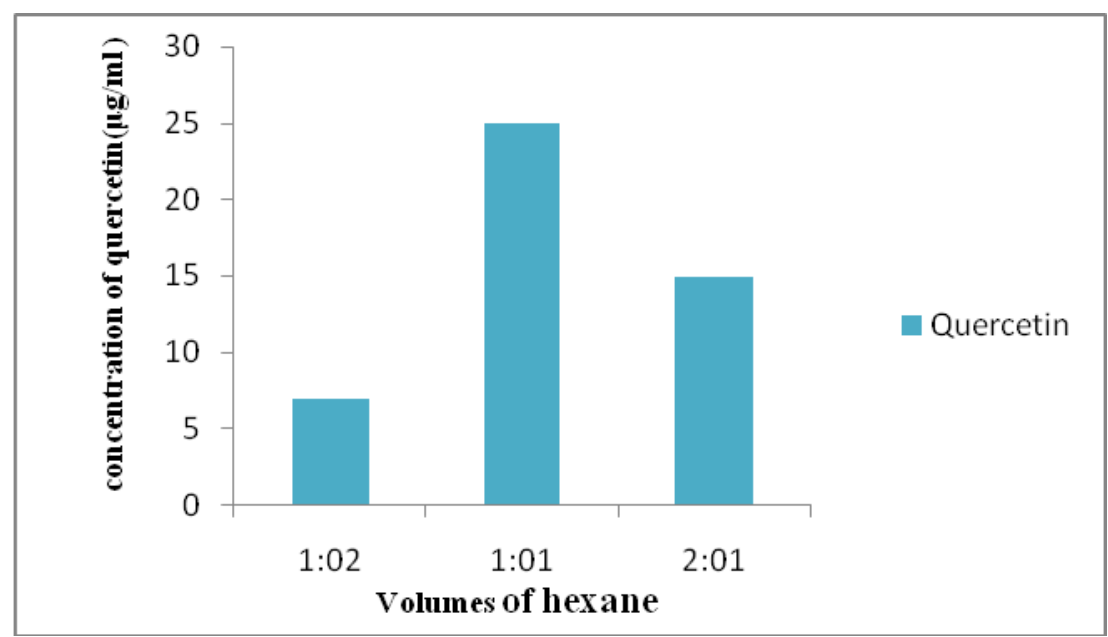

Fig.6. volume with hexane

6. EFFECT OF EXTRACTION TIME WITH HEXANE ON EXTRACTION OF QUERCETIN:

To investigate the influence of hexane on extraction of quercetin, different time intervals were taken viz., 1 , 2,3and 4 hours. Solvent- solvent extraction was done with hexane as one of the solvent. It was observed that, at the first hour, the concentration of quercetin was $37 \mu \mathrm{g} / \mathrm{ml}$. (Fig. 7)

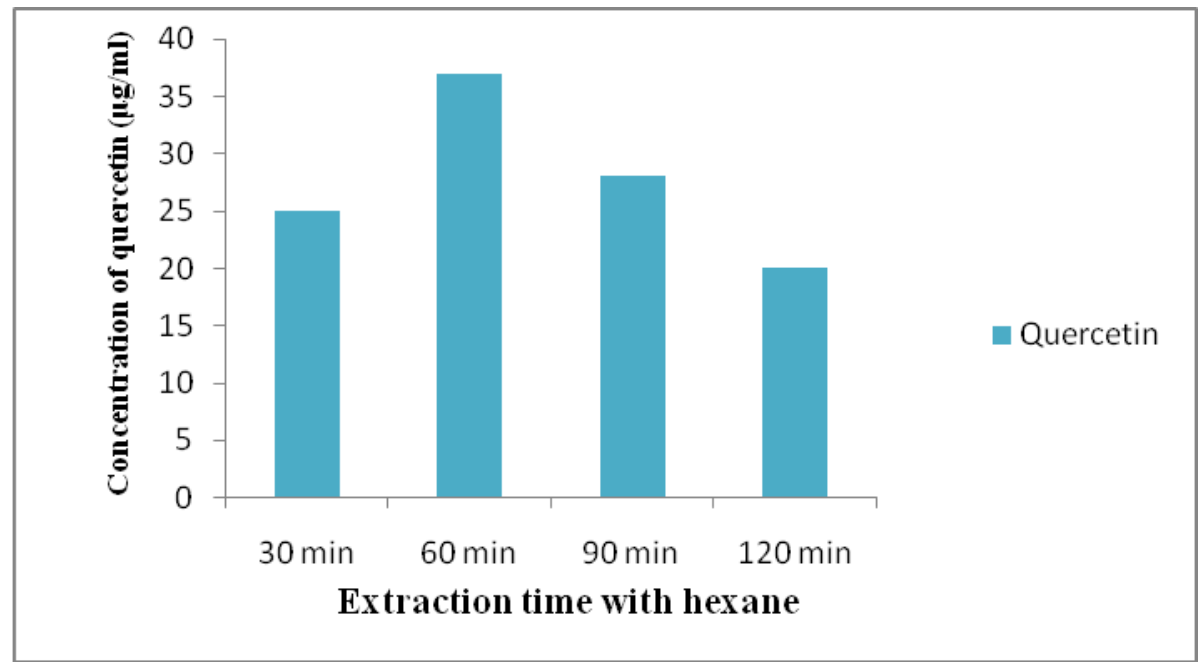

Fig.7. Effect of extraction time with hexane on extraction of Quercetin 


\title{
International Journal of Innovative Research in Science, Engineering and Technology
}

\author{
(An ISO 3297: 2007 Certified Organization)
}

Vol. 4, Issue 5, May 2015

\section{B. RESULT OF MODELLING OF EXTRACTION OF QUERCETIN USING SOXHLET EXTRACTOR}

Methanol was found to be the best solvent for the extraction of Quercetin from pineapple peel by soxhlet extractor. It was carried out for $90 \mathrm{~min}$ and an optimum concentration obtained at 50 min with a concentration of $50 \mu \mathrm{g} / \mathrm{ml}$. Modelling of extration of quercetin using soxhlet extractor apparatus was studied in order to describe the quercetin from the peel of pineapple to the bulk of the solvent. The mass transfer coefficient is constant.The solvent in the extractor is perfectly mixed, while the transfer resistance in the liquid phase is negligible and the quercetin concentration in the solvent depends only on time. The transfer of the quercetin was a diffusion phenomenon and independent of time. By this hypothesis an equation can be developed. Soxhlet extractor was run for 90 minutes at 60 $80^{\circ} \mathrm{C}$ with $80 \%$ methanol as solvent.

$$
\mathbf{E}(\mathbf{t})=\mathbf{A t ^ { 2 }}+\mathbf{B t}+\mathbf{C}
$$

Where $\mathrm{A}, \mathrm{B} \& \mathrm{C}$ are constants, $\mathrm{E}_{\mathrm{s}}=$ yield $\operatorname{extract}(\mu \mathrm{g} / \mathrm{ml}$ of quercetin) and $\mathrm{t}=$ extraction time $(\mathrm{min})$. The final form of proposed equation is $E(t)=-\mathbf{0 . 0 1 8 t ^ { 2 }}+\mathbf{1 . 5 9 1 t}$ with $R^{2}=\mathbf{0 . 8 9 4}$

Table: Effect of Yield extract with extraction time on Quercetin

\begin{tabular}{|c|c|c|}
\hline $\mathrm{S} \mathrm{NO}$ & Time(min) & $\begin{array}{c}\text { Yield extract } \\
\text { ( } \mu \text { g of quercetin/gm of dried } \\
\text { sample) }\end{array}$ \\
\hline 1 & 10 & 9 \\
\hline 2 & 20 & 20 \\
\hline 3 & 30 & 30 \\
\hline 4 & 40 & 45 \\
\hline 5 & 50 & 50 \\
\hline 6 & 60 & 46 \\
\hline 7 & 70 & 40 \\
\hline 8 & 80 & 36 \\
\hline 9 & 90 & 26 \\
\hline
\end{tabular}

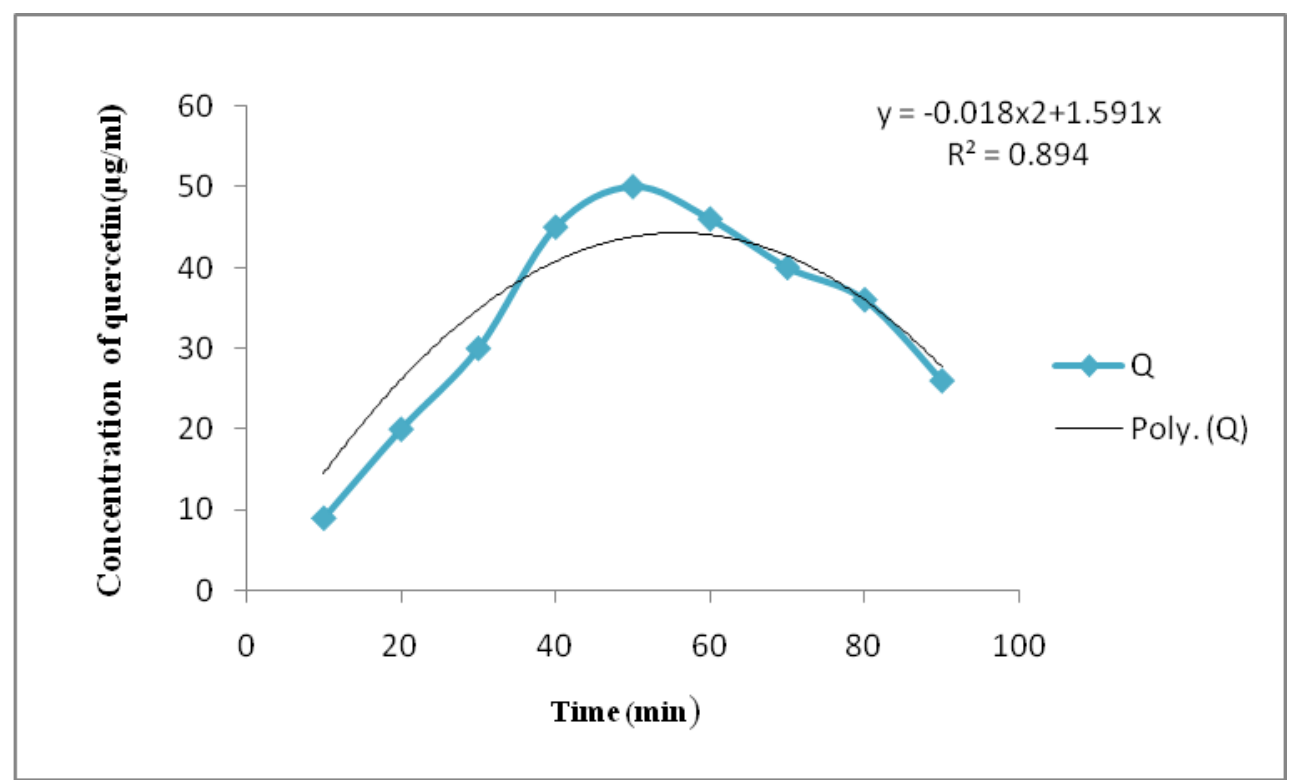

Fig.8. Effect of Yield extract with extraction time on quercetin 


\title{
International Journal of Innovative Research in Science, Engineering and Technology
}

\author{
(An ISO 3297: 2007 Certified Organization)
}

Vol. 4, Issue 5, May 2015

\section{CONCLUSION}

The present study was intended for the optimization of extraction of Quercetin and its various physicochemical parameters have been studied. For the extraction of Quercetin the optimum results were observed for the effect of different solvents, soaking time, different solvent percentages, effect of $\mathrm{pH}$, different volumes of hexane with methanol as solvent,extraction time with hexane were methanol, 1day, $80 \%$ (v/v), 7.0, 1:1 ratio and $1 \mathrm{hr}$ respectively. The highest Quercetin concentration for optimized condition was $37 \mu \mathrm{g} / \mathrm{ml}$.

Methanol was found to be the best solvent for the extraction of Quercetin from pineapple peel by soxhlet extractor. It was carried out for $90 \mathrm{~min}$ and an optimum concentration obtained at 50 min with a concentration of $50 \mu \mathrm{g} / \mathrm{ml}$.This Solvent extraction using soxhlet extractor was conduct to verify the mathematical model proposed in this work. The final form of proposed models were $\mathrm{E}(\mathrm{t})=\mathrm{At}^{2}+\mathrm{Bt}+\mathrm{C}$ Where $\mathrm{A}, \mathrm{B} \& \mathrm{C}$ are constants, $\mathrm{E}_{\mathrm{s}}=\mathrm{yield}$ extract $(\mu \mathrm{g} / \mathrm{ml}$ of quercetin) and $t=e x t r a c t i o n$ time $(\mathrm{min})$. The final form of proposed equation is $\mathrm{E}(\mathrm{t})=-0.018 \mathrm{t}^{2}+1.591 \mathrm{t}$ with $\mathrm{R}^{2}=0.894$.

\section{REFERENCES}

[1] Boots AW, Haenen GR, Bast A, "Health effects of quercetin: from antioxidant to nutraceutical". Eur J Pharmacol .Vol.582 (2-3):pp 325-37,2008 [2] Boots AW, Li H, Schins RP, Duffin R, Heemskerk JW, Bast A, Haenen GR, “The quercetin paradox". Toxicol Appl Pharmacol. Vol.222 (1): pp 89-96,2007.

[3] Cai J, Nelson KC, Wu M, Sternberg P Jr, Jones DP, “ Oxidative damage and protection of the RPE”. Prog Retin Eye Res. Vol. 19(2):pp 205221,2000 .

[4] Mackraj I, Govender T, Ramesar S, “The antihypertensive effects of quercetin in a salt-sensitive model of hypertension". J Cardiovasc Pharmacol. 51(3): pp 239-45, 2008.

[5] Egert S, Bosy-Westphal A, Seiberl J, "Quercetin reduces systolic blood pressure and plasma oxidised low-density lipoprotein concentrations in overweight subjects with a high-cardiovascular disease risk phenotype: a dboule-blinded, placebo-controlled cross-over study". Br J Nutr. Vol.102 (7):pp 1065-74,2009.

[6] Lam TK, Rotunno M, Lubin JH, "Dietary quercetin, quercetin-gene interaction, and metabolic gene expression in lung tissue and lung cancer risk". Journal of Carcinogenesis. Vol. 31(4): pp 634-42, 2010.

[7] Lamson DW, Brignall MS, “Antioxidants and cancer III: quercetin”. Alt Med Rev. Vol.5 (3): pp 196-208, 2000.

[8] Giuliani C, Noguchi Y, Harii N, Napolitano G, Tatone D, Bucci I, Piantelli M, Monaco F, Kohn LD, “ The flavonoid quercetin regulates growth and gene expression in rat FRTL-5 thyroid cells". J Endocrinology. Vol.149 (1):pp 84-92,2008.

[9] Edwards RL, Lyon T, Litwin SE, Rabovsky A, Symons JD, Jalili T, " Quercetin reduces blood pressure in hypertensive subjects". J Nutr. Vol.137 (11):pp 2405-11,2007.

[10] Guardia T, Rotelli AE, Juarez AO, Pelzer LE, "Anti-inflammatory properties of plant flavonoids. Effects of rutin, quercetin and hesperidin on adjuvant arthritis in rat". J Farmaco. Vol.56 (9): pp 683-687, 2001.

[11] Avani Patel, Amit Patel, Dr.N.M.Patel, "Estimation of Flavonoid,Polyphenolic Content and In-vitro Antioxidant Capacity of leaves of Tephrosia purpurea Linn.(Leguminosae)".JJPSR,Vol.1(1):pp 66-77,2010.

[12] Dr. Meena Vangalapati, Gnana Madhuri Y, Vidya Sagar T, Ravi Raju V and Satyadev L K, "Experimental studies and Development of Modelling equation of Quercetin from Raphanus Sativus using Soxhlet Extractor" International Journal of Innovative Research in Science,Engineering and Technology.Vol. 3: pp 12215-12222, 2014. 